\title{
MUNCULNYA KREATIVITAS SISWA AKIBAT ILL STRUCTURED MATHEMATICAL PROBLEM
}

\author{
Abdillah, Ajeng Gelora Mastuti \\ Jurusan Pendidikan Matematika IAIN Ambon \\ abdillah@iainambon.ac.id
}

\begin{abstract}
Abstrak
Salah satu tujuan pembelajaran matematika adalah mengembangkan pemikiran. Untuk itu, perlu dilakukan penanganan dan penyelesaian masalah tersebut. Seorang siswa dalam menyelesaikan masalah harus berpikir, menganalisis masalah, mencari formulasi secara kritis yang sesuai dengan masalah, memeriksa data formulasi dan berusaha mencari strategi pemecahan masalah yang memungkinkan mendapatkan solusi.

Pada banyak penelitian telah mengungkapkan tentang berpikir kreatif siswa, tapi belum ada hasil penelitian yang mengungkapkan secara detail bagaimana munculnya kreativitas siswa akibat menyelesaikan ill structured mathematical problem. Untuk itu, melalui penelitian kualitatif deskriptif, yang dilakukan pada beberapa kabupaten/kota di Provinsi Sulawesi Selatan dan Jawa Timur. Terungkap secara detail proses munculnya kreativitas siswa akibat menyelesaikan ill structured mathematical problem.

Hasilnya adalah muncul kreativitas siswa dalam menyelesaikan ill structured mathematical problem. Kreativitas terjadi melalui proses membuat jawaban yang beragam dan benar dalam memecahkan masalah (fluency), karena ISMP memiliki beberapa jalur solusi; kemudian 2) memecahkan masalah dengan berbagai cara yang berbeda (flexibility), karena ISMP memiliki konteks yang spesifik dan situasi yang kompleks; dan 3) membuat berbagai jawaban yang berbeda dan benar dalam memecahkan masalah (novelty) karena ISMP sesuai dengan kehidupan sehari-hari sehingga siswa merasa mengalami masalah tersebut. Sehingga dengan think aloud dan klarifikasi melalui wawancara, siswa mengungkapkan proses kreativitasnya dalam menyelesaikan masalah yang disajikan.
\end{abstract}

\section{Kata kunci: kreativitas siswa, Ill Structured Mathematical Problem}

\begin{abstract}
One of the goals of learning mathematics is to develop thinking. Therefore, it is necessary to handle and solve the problem. A student in solving a problem must think, analyze the problem, find the formulation critically according to the problem, check the formulation data and try to find a problem solving strategy that allows the solution.

In many studies have revealed about creative thinking of students, but no research results reveal in detail how the emergence of student creativity due to solve ill structured mathematical problem. For that, through descriptive qualitative research, conducted on several districts / cities in the Province of South Sulawesi and East Java. Revealed in detail the process of the emergence of student creativity due to complete ill structured mathematical problem.

The result shows that there is exist student's creativity when solve ill stuctured mathematical problem. 1) Creativity are made by making variety and correct answer when solve problem (fluency) because ISMP has some pathed solution, then 2) solved problem into different way (flexibility) because ISMP has detailed context and complexity situtation and 3) making different and correct answers when solve the problem (novelty) because ISMP based on real life context so that student can feel the problem. Thus, think aloud and clarification by depth interview, student can express their creativity process when solve the problem.
\end{abstract}

Keywords: exploration, students' creativity 
Sitasi: Abdillah. 2018. Munculnya Kreativitas Siswa Akibat Ill Structured Mathematical Problem. Matematika dan Pembelajaran, 6(1), 48-59

\section{PENDAHULUAN}

Beberapa hasil penelitian yang menunjukkan pentingnya kreativitas (Ayllon, dkk 2016; Karwowski, dkk. 2017; Sanders, 2016). Ayllon (2016) mengemukakan dalam hasil penelitiannya bahwa saat ini misi prioritas guru adalah mengidentifikasi dan

mengembangkan kreativitas siswa, dan mereka membutuhkan lingkungan yang memadai untuk pembelajaran kreatif. Lebih lanjut Karwowski, dkk. 2017 menyatakan bahwa model teoritis kreativitas dan imajinasi telah dimulai. Fokusnya adalah menggunakan heuristik dan proses pemecahan masalah matematika sebagai ilustrasi. Proses pemecahan masalah melibatkan kemampuan kreatif, keterbukaan, kemandirian, dan aspek imajinasi kreatif yang berbeda-beda. Terutama kejelasan, orisinalitas, dan transformatif. Sanders (2016), Kurikulum Australia menganjurkan berpikir kritis dan kreatif sebagai keterampilan penting untuk mengembangkan pelajar yang sukses dan otonom melintasi kurikulum.

Sejalan dengan hasil penelitian para ahli tersebut, Peraturan Menteri Pendidikan dan Kebudayaan nomor 22 tahun 2016 tentang standar proses pendidikan dasar dan menengah bahwa kompetensi pengetahuan yang harus dimiliki siswa adalah mengingat, memahami, menerapkan, menganalisis, mengevaluasi, mencipta. Pada kompetensi keterampilan diperoleh melalui aktivitas mengamati, menanya, mencoba, menalar, menyaji, dan mencipta. Memahami, menerapkan dan menganalisis termasuk dalam komponen-komponen yang harus dimiliki dalam pemecahan masalah. Berdasarkan penjelasan tersebut maka memecahkan masalah merupakan salah satu aspek penting yang harus dimiliki siswa perlu dikembangkan dalam penugasan matematika. Hal tersebut sejalan dengan tujuan utama pengajaran matematika adalah mengembangkan pemikiran (Ayllon, dkk. 2016). Siswa perlu memiliki kemampuan memperoleh, memilih dan mengolah informasi untuk bertahan pada keadaan yang selalu berubah, tidak pasti dan kompetitif. Kemampuan ini membutuhkan kemampuan berpikir kritis, sistematis, logis, kreatif dan kemampuan bekerjasama yang efektif. Cara berpikir seperti ini dapat dikembangkan melalui belajar matematika, karena matematika memiliki struktur dan keterkaitan yang kuat dan jelas antar konsepnya sehingga memungkinkan siswa terampil berpikir rasional (Depdiknas, 2003).

Lebih lanjut sesuai Standar Isi dalam Permendiknas Nomor 22 Tahun 2006, mata pelajaran matematika diberikan untuk membekali siswa dengan kemampuan berpikir logis, analitis, sistematis, kritis, dan kreatif, serta kemampuan bekerjasama. Kompetensi tersebut diperlukan agar siswa dapat memiliki kemampuan memperoleh, mengelola, dan memanfaatkan informasi untuk bertahan hidup pada keadaan yang selalu berubah, tidak pasti, dan kompetitif. Demikian pula tujuan yang diharapkan oleh National Council of Teachers Mathematics (NCTM) dalam pembelajaran matematika. NCTM (2000) menetapkan lima standar kemampuan matematis yang harus dimiliki oleh siswa, yaitu 
kemampuan pemecahan masalah (problem solving), kemampuan komunikasi (communication), kemampuan koneksi (connection), kemampuan penalaran (reasoning), dan kemampuan representasi (representation).

Pada banyak penelitian telah mengungkapkan tentang pentingnya kreativitas siswa dan guru dalam pembelajaran matematika, namun belum ada hasil penelitian yang mengungkapkan secara detail bagaimana munculnya kreativitas siswa akibat ill structured mathematical problem. Sehingga apabila tidak dilakukan penelitian untuk mengeksplorasi munculnya kreativitas siswa akibat ill structured mathematical problem, maka tidak akan ada referensi tentang proses munculnya kreativitas siswa sebagai akibat siswa menyelesaikan ill structured mathematical problem. Dengan demikian, penting untuk diteliti lebih lanjut tentang proses munculnya kreativitas siswa sebagai akibat siswa menyelesaikan ill structured mathematical problem. Ill structured mathematical problem yang dimaksud dalam tulisan ini adalah jenis masalah yang dihadapi dalam praktek kehidupan sehari-hari, memuat konten matematika, melibatkan unsur-unsur yang tidak diketahui, memiliki hubungan beberapa konsep, beberapa solusi, jalur solusi sehingga mengharuskan seseorang untuk mengekspresikan pendapat pribadi karena terkait aktivitas interpersonal unik manusia.

\section{METODE}

Pendekatan yang digunakan dalam penelitian ini adalah menggunakan pendekatan kualitatif dengan jenis penelitian deskriptif-eksploratif (Miles, M.B \& Huberman, A.M 1992). Bila ditinjau dari tujuan penelitian ini adalah untuk menghasilkan deskripsi proses munculnya kreativitas siswa sebagai akibat menyelesaikan ill structured mathematical problem. Untuk mengungkap atau memperoleh hasil deskripsi proses berpikir yang digunakan subjek dalam menyelesaikan ill structured mathematical problems, peneliti berusaha melakukan pemeriksaan secara teliti dan hati-hati serta secara detail dan mendalam (dengan melakukan eksplorasi) terhadap subjek mengenai apa yang dilakukan, ditulis, diucapkan, gerakan tubuh, atau bahkan apa yang dipikirkan mereka pada saat menyelesaikan soal. Oleh karenanya peneliti bertindak sebagai instrumen kunci, keberadaannya mutlak diperlukan dan tidak dapat diwakilkan oleh orang lain atau dengan sesuatu yang lain (Creswell, 2012). Dalam hal memperoleh data, peneliti menggunakan insrumen bantu berupa ill structured mathematical problems (ISMP), alat perekam audio dan audiovisual (handycam) sebagai instrumen pembantu.

Peneliti memberikan ISMP ke pada 24 siswa kelas XII SMA/SMK. Dengan rincian 13 siswa SMAN 3 Jombang, 6 siswa SMKN 5 Bittoeng, 1 siswa SMKN 2 Pinrang, 2 siswa SMAN 11 Unggulan Pinrang, 2 siswa SMKN 4 Malang. Tahap pertama, peneliti melatih setiap siswa melakukan think alouds dengan menyelesaikan soal matematika yang mudah, yaitu menentukan luas jajar genjang, jika diketahui panjang dua sisi sejajarnya adalah masing-masing $4 \mathrm{~cm}$ dan $5 \mathrm{~cm}$. Tahap kedua, subjek menyelesaikan tugas pemecahan masalah matematis dengan berpikir keras dan mengungkapkan hal-hal yang dipikirkan. Tahap ketiga, peneliti memutar ulang hasil rekaman subjek pada saat menyelesaikan tugas pemecahan masalah matematik, kemudian peneliti dengan subjek melihat bersama hasil rekaman tersebut sambil peneliti melakukan wawancara berbasis tugas. 
Dalam tulisan ini, Subjek penelitian yang dipaparkan adalah seorang siswa kelas XII SMAN 03 Jombang. Subjek ini dipilih setelah melalui proses penjaringan subjek pada lima sekolah di Provinsi Sulawesi Selatan dan Jawa Timur. Dengan cara melakukan observasi langsung pada siswa serta rekomendasi guru bidang studi matematika kemudian diberikan ISMP. Adapun ISMP yang digunakan adalah sebagai berikut:

"Harga satu baju di Toko A adalah Rp 5.000,- lebih mahal dari harga satu baju di Toko B. Toko B memberikan diskon $10 \%$ untuk pembelian setiap baju. Toko A memberi harga khusus, yaitu jika seseorang membeli lebih dari satu baju maka akan memperoleh diskon $40 \%$ untuk pembelian kedua setiap baju. Jika Anda ingin membeli 3 baju, maka bagaimana caranya agar mengeluarkan biaya pembelian termurah? berikan penjelasan tentang pembelian baju di kedua toko tersebut!"

\section{HASIL PENELITIAN}

Bagian ini menguraikan tentang paparan dan analisis data secara kualitatif tentang munculnya kreativitas siswa sebagai akibat siswa menyelesaikan ill structured mathematical problem yang disajikan oleh peneliti. Pemaparan data untuk mendeskripsikan munculnya kreativitas siswa. Dari 24 siswa yang telah diberikan ISMP, diperoleh 2 siswa yang kreatif. Namun dalam artikel ini hanya satu siswa dipaparkan.

Subjek mengawali proses penyelesaian masalahnya dengan mengidentifikasi fakta dan tujuan dalam memahami masalah ISMP. Subjek mengalami interaksi berpikir intuitif dan analitik. Interaksi tersebut diawali dengan berpikir analitik. Berpikir analitik diketahui dari Subjek pada saat mengurai ISMP atas berbagai bagian dan menelaah bagian itu serta menghubungkan antar bagian. Mengurai dan menelaah kalimat pertama ISMP menjadi dua bagian, sehingga menghasilkan persamaan di toko B dan toko A; menelaah kalimat kedua sehingga memahami bahwa diskon di toko B itu untuk setiap pembelian; menelaah kalimat ketiga sehingga memahami bahwa ada harga khusus untuk pembelian kedua di toko A; kemudian menghubungkan cara membeli tiga baju. Berikutnya, Subjek mengalami berpikir intuitif sesaat setelah Subjek selesai menelaah kalimat pertanyaan ISMP, ia sempat menduga bahwa membeli semua baju di toko A akan memberikan pengeluaran termurah. Namun, hal tersebut tidak dijadikan dasar dalam mengambil keputusan, sehingga Subjek meneruskan berpikir analitiknya.

Pada tahap selanjutnya, Subjek mengalami interaksi berpikir intuitif dan analitik serta melakukan penambahan informasi dalam menentukan besar pengeluaran di toko A dan toko B. Interaksi diawali dengan berpikir intuitif yang disertai penambahan informasi tampak pada saat akan menentukan harga satu baju di toko B. Harga ditentukan untuk mengetahui besar pengeluaran jika membeli semua baju di toko B, sehingga Subjek memutuskan menambahkan informasi berupa angka sebesar 20.000. Hal tersebut merupakan berpikir intuitif intensi yaitu ide yang muncul pada diri Subjek sebagai strategi guess and test dalam membuat keputusan berdasarkan feeling dan intrinsik yang diperkirakan benar sehingga menghasilkan jawaban spontan pada pemecahan masalah yang dihadapi. Selanjutnya, Subjek melakukan berpikir analitik untuk mengetahui besar pengeluaran jika membeli semua baju di toko A, yaitu dengan mengurai dan menelaah 
kalimat ketiga dan kalimat pertanyaan ISMP yang disertai pengalihan/pengubahan informasi. Berikut Gambar 1. hasil potongan hasil pekerjaan subjek mulai mengawali proses penyelesaian sampai dengan menentukan satu alternatif penyelesaian.

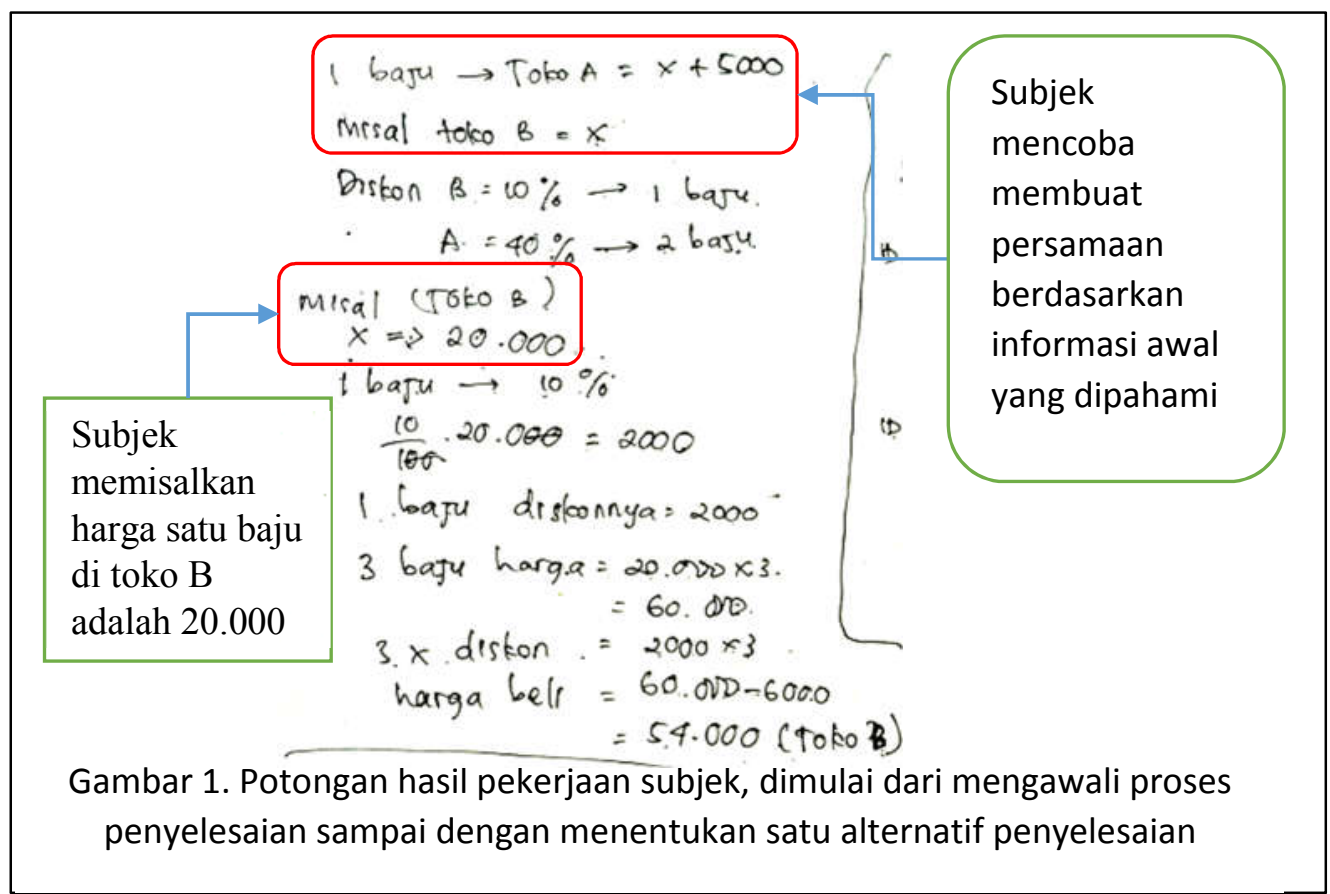

Selanjutnya berpikir analitik yang disertai dengan pengalihan/pengubahan informasi dalam mengurai dan menelaah kalimat ke tiga dan kalimat pertanyaan ISMP terkait besar pengeluaran jika membeli baju di toko A. Subjek mengawali solusi dengan mengurai dan menelaah kalimat ke tiga dan kalimat pertanyaan ISMP kemudian menghubungkan keduanya sehingga masalahnya adalah bagaimana cara membeli tiga baju semuanya di toko A dan membandingkan besar pengeluaran di toko A dengan toko B.

Selanjutnya pada saat membuat rencana strategi penyelesaian. Subjek mengalami berpikir analitik dan mengubah pertanyaan. Berpikir analitik diawali dengan munculnya pengubahan pertanyaan oleh Subjek, sehingga langkah selanjutnya adalah mengurai dan menelaah alternatif-alternatif solusi yang dapat dipilih. Berpikir analitik selanjutnya adalah ketika akan menetapkan pilihan akhir yang akan direkomendasikan untuk dipilih. Subjek melihat kembali tulisan-tulisan sebelumnya, kemudian membuat daftar semua alternatif solusi yang dapat dipilih. Dengan demikian Subjek menetapkan pilihan pada alternatif keempat yang memberikan pengeluaran termurah di antara enam alternatif.

\section{PEMBAHASAN}

Berikut ini pembahasan tentang munculnya kreativitas siswa sebagai akibat Ill Structured Problem Mathematical yang disajikan ke siswa. Pada masalah yang disajikan tersebut memuat dua hal penting: pertama, tidak ada prosedur baku yang digunakan untuk menyelesaikan masalah tersebut; kedua memunculkan dilema berupa pilihan antara 
membeli tiga pasang sepatu di toko A, tiga pasang sepatu di toko B, dua pasang sepatu di toko A dan satu pasang sepatu di toko B, atau satu pasang sepatu di toko A dan dua pasang sepatu di toko B; ketiga masalah pembelian ketiga di toko S tidak terdefinisi dengan baik; keempat, masalah di kedua toko didasarkan pada situasi kehidupan nyata dan memiliki keterbukaan; dan kelima, situasi yang kompleks disajikan, bagaimana caranya agar mengeluarkan biaya pembelian termurah?

Beberapa pendapat ahli tentang Ill-structured problems. Menurut Wood (1983) nampak tidak jelas karena satu atau lebih dari unsur-unsur masalah tidak diketahui. Memiliki definisi yang samar-samar atau tujuan yang tidak jelas dan kendala tidak dinyatakan (Voss, 1988). Memiliki beberapa solusi, jalur solusi, atau tidak ada solusi sama sekali (Kitchener, 1983) yaitu, kesepakatan tidak berdasarkan konsensus pada solusi yang tepat. Memiliki parameter lebih sedikit yang dapat dimanipulasi. Memiliki hubungan antara konsep-konsep, aturan, dan prinsip-prinsip yang tidak sesuai antara kasus (Jonassen, 1997). Akibatnya, mengharuskan siswa untuk mengekspresikan pendapat pribadi atau keyakinan tentang masalah ini, dan karena masalah ini adalah aktivitas interpersonal unik manusia (Abdillah, dkk., 2017); mengharuskan siswa untuk membuat penilaian tentang masalah dan dapat mempertahankan pendapat mereka (Jonassen,1997). Dengan demikian ill structured problems yang disajikan kepada siswa adalah masalah yang melibatkan unsur-unsur yang tidak diketahui, memiliki hubungan beberapa konsep, beberapa solusi, jalur solusi sehingga mengharuskan seseorang untuk mengekspresikan pendapat pribadi karena terkait aktivitas interpersonal unik manusia.

Lebih lanjut, Ill-structured problems adalah jenis masalah yang dihadapi dalam praktek kehidupan sehari-hari, sehingga masalah ini biasanya memunculkan dilema berupa pilihan (Jonassen,1997). Karena Ill-structured problems ini tidak hanya dibatasi oleh domain konten yang dipelajari di kelas, solusinya tidak konvergen. Masalah ini juga memungkinkan memerlukan integrasi beberapa domain konten. Mempunyai banyak alternatif pemecahan masalah (Abdillah, 2017). Lebih lanjut, Abdillah, dkk (2016) berpendapat bahwa dalam menjelajahi pengambilan keputusan seseorang akan memerlukan sebuah teori sebagai panduan. Keputusan siswa dalam memilih beberapa pilihan yang dibuat adalah tindakan alternatif dari serangkaian tindakan atau strategi yang dibuat siswa. Tindakan tersebut dapat dilakukan secara intuitif, analitik atau interaktif. Namun, karena masalah ini terletak dalam praktek kehidupan sehari-hari, sehingga jauh lebih menarik dan bermakna bagi siswa untuk mendefinisikan masalah dan menentukan apakah informasi dan keterampilan yang diperlukan untuk membantu mengatasi masalah yang dihadapi.

Ill-structured problems muncul dari konteks yang spesifik, mempunyai karakteristik sebagai berikut: pertama, aspek situasi tidak konkrit; kedua, masalah tidak terdefinisi dengan baik; ketiga, masalah ini didasarkan pada situasi kehidupan nyata dan memiliki keterbukaan; dan akhirnya, situasi yang kompleks disajikan (Chi \& Glaser, 1985). Kim, Lee, Hong \& Kim, (2011) mendefinisikan Ill-structured problems sebagai authenticity (keaslian), complexity (kompleksitas), dan openness (keterbukaan) sebagai sifat-sifat dari Ill-structured problems. Keaslian berarti bahwa sesuai dengan kehidupan sehari-hari, dengan homework matematika atau masalah yang menggambarkan kehidupan nyata di luar sekolah (Palm, 2008). Suatu masalah dapat dikatakan memiliki keaslian, 
apabila masalah tersebut mencakup konteks kehidupan sehari-hari dan cukup relevan untuk menyimpulkan bagian integral dari situasi yang sebenarnya.

Dalam hal kompleksitas, Jonassen (1997) memandang bahwa atribut kompleksitas memuat: adanya ketidakpastian konsep, aturan dan prinsip-prinsip yang diperlukan untuk memecahkan masalah, atau bagaimana masalah tersebut diorganisir. Hubungan antara konsep dan aturan dan prinsip-prinsip yang tidak tetapkan. Dalam hal keterbukaan, Jonassen mengatakan: pertama, beberapa kriteria evaluasi harus ada untuk memecahkan masalah; kedua, kejelasan maksud dari masalah tidak disajikan; ketiga, siswa harus mengungkapkan pendapat pribadi dan keyakinan tentang masalah; keempat, disarankan agar siswa men-judge dan mempertahankan masalah. Shin, Jonassen \& McGee (2003) mengatakan bahwa sifat keterbukaan memungkinkan siswa untuk menempatkan berbagai penafsiran tentang pemecahan masalah dan untuk membenarkan interpretasi mereka.

Akibat dari masalah ill structured problems yang diberikan ke siswa tersebut. Proses kreativitas siswa terungkap pada saat menyelesaikan masalah yang disajikan. Siswa berpikir analitik dalam mengubah pertanyaan. Hal tersebut terjadi setelah memperoleh nilai diskon $44 \%$ untuk baju ketiga di toko A. Sehingga langkah selanjutnya adalah mengurai dan menelaah alternatif-alternatif solusi yang dapat dipilih.

Apabila ditinjau dari komponen berpikir kreatif Silver (1997) maka berpikir siswa dalam menyelesaikan masalah ill structured mathematical problems yang disajikan peneliti merupakan memenuhi kriteria berpikir kreatif. Silver (1997) menjelaskan bahwa untuk menilai kemampuan berpikir kreatif anak dan orang dewasa dapat dilakukan dengan menggunakan "The Torrance Test of Creative Thinking (TTCT)". Tiga komponen yang digunakan untuk menilai kemampuan berpikir kreatif melalui TTCT adalah kefasihan (fluency), fleksibilitas (fleksibility) dan kebaruan (novelty). Berikut penjabaran pemenuhan ketiga komponen yang dialami siswa.

Komponen pertama, yaitu kefasihan (fluency), dengan membuat jawaban yang beragam dan benar dalam memecahkan masalah. Hal tersebut tampak pada siswa ketika membuat tiga alternatif solusi, yaitu (a) total pengeluaran di toko A sama dengan total pengeluaran di toko B, sehingga dapat menentukan pilihan dengan bebas, (b) membeli semua baju di toko A, (c) membeli semua baju di toko B. Berikut Gambar 2. Struktur model Proses Kreativitas Siswa dalam Menyelesaikan Masalah Ill Structured Problem pada komponen fluency. 


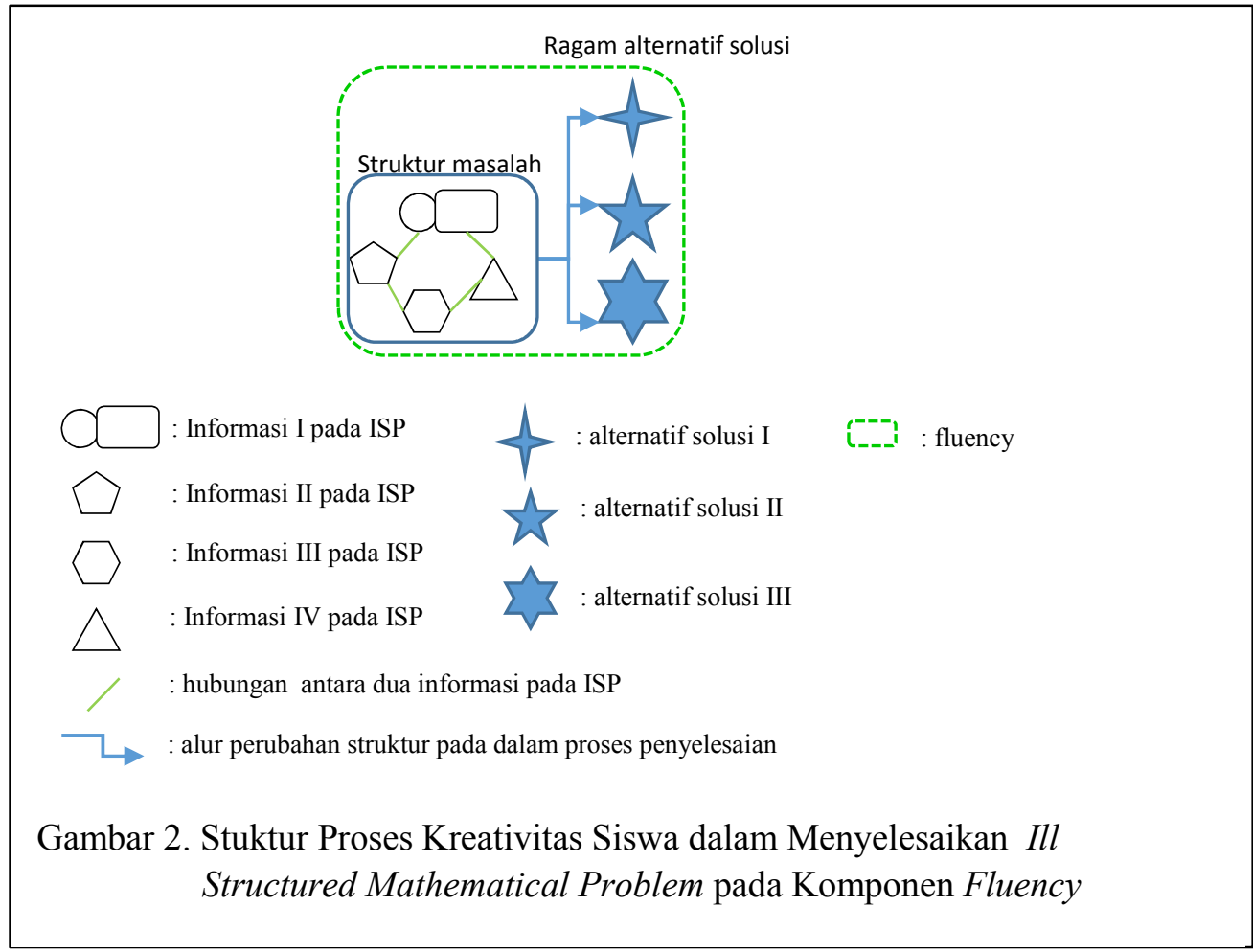

Komponen kedua fleksibilitas (flexibility), siswa memecahkan masalah dengan berbagai cara yang berbeda. Hal tersebut tampak dari penjelasan berikut:

1) Siswa mengurai bahwa setiap baju di toko $B$ mendapat diskon $10 \%$, sehingga supaya total pengeluaran di toko A sama dengan total pengeluaran di toko B, maka Toko A harus memberlakukan pembelian baju pertama harga normal, pembelian baju kedua diskon $40 \%$, dan pembelian baju ketiga diskon $44 \%$.

2) Siswa menelaah bahwa pilihan akan jatuh pada toko B, yaitu memilih membeli semua baju di toko B, apabila baju ketiga di toko A tidak mendapat diskon. Sesuai dengan redaksi masalah matematis, baju ketiga di toko A tidak ada keterangan, sehingga bila harga satu baju di toko A sebesar 25.000, maka pembelian baju pertama harga normal sebesar 25.000, pembelian baju kedua mendapat diskon $40 \%$ sebesar 15.000 , dan pembelian baju ketiga kembali lagi ke harga normal sebesar 25.000. Berarti total pengeluaran di toko A sebesar 65.000 apabila pembelian baju ketiga tidak mendapat diskon. Jadi lebih mahal dibanding membeli baju semua di B.

3) Siswa menelaah bahwa untuk memilih membeli semua baju di toko A, maka syaratnya adalah baju ketiga di toko A harus memberlakukan diskon $44 \%$ ke atas. Karena pemberlakuan diskon $44 \%$ untuk pembelian baju ketiga di toko A akan menyebabkan total pengeluaran di toko A sama dengan total pengeluaran di toko B. Dengan demikian apabila toko A memberlakukan diskon di atas $44 \%$ untuk pembelian baju ketiga, maka akan diperoleh total pengeluaran di toko A lebih kecil atau lebih murah dari total pengeluaran di toko B.

Berikut Gambar 3. Struktur model Proses Kreativitas Siswa dalam Menyelesaikan Masalah Ill Structured Problem pada Komponen Fluency dan Flexibility. 


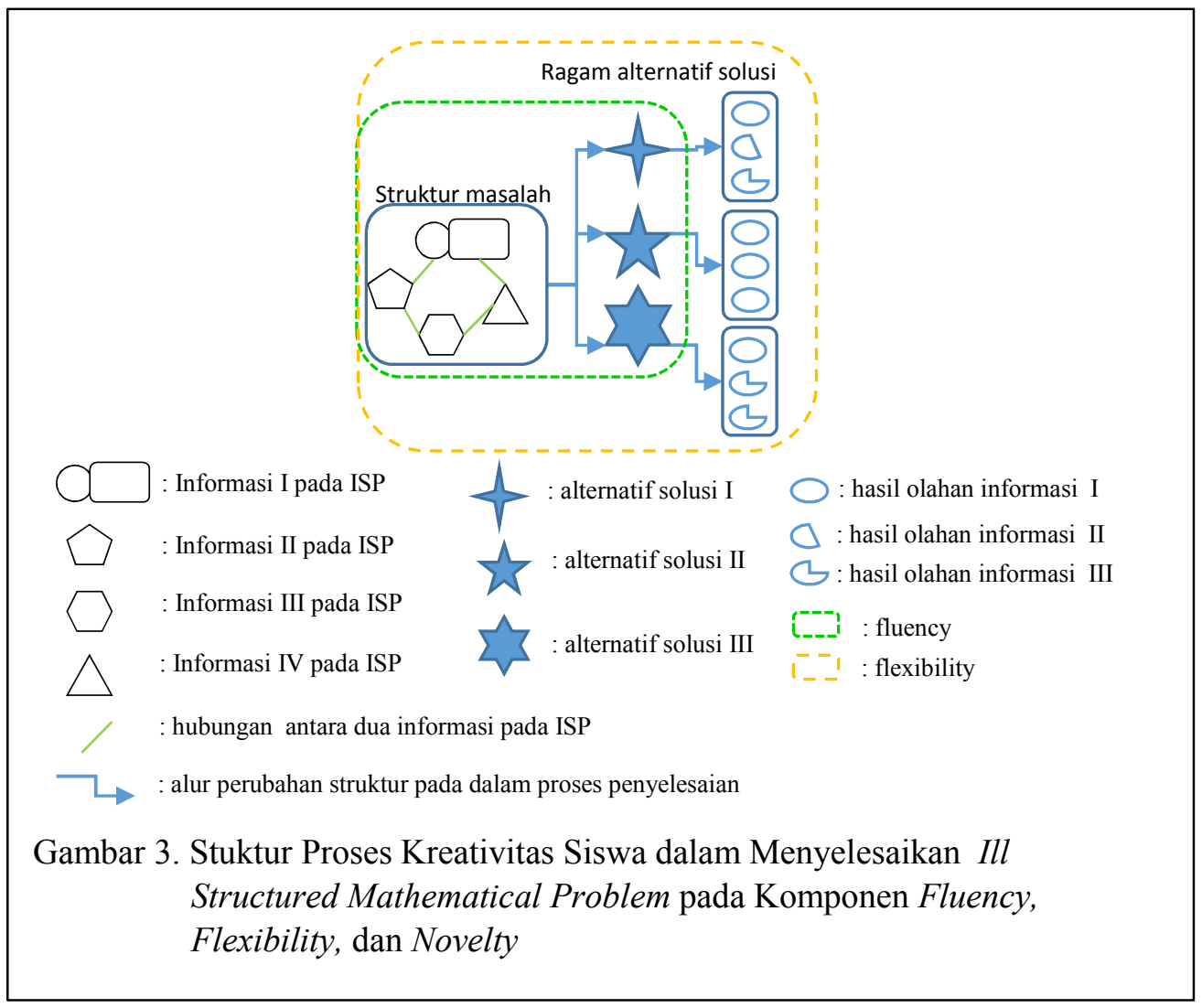

Komponen ketiga, kebaruan (novelty) siswa membuat berbagai jawaban yang berbeda dan benar dalam memecahkan masalah. Hal tersebut dapat diketahui dari strategi siswa dalam memecahkan masalah. Mencari diskon baju ketiga di toko A agar hasilnya dapat diakumulasi dengan pembelian baju kedua dan baju ketiga, kemudian dibandingkan dengan pembelian tiga baju di toko B. Oleh karena itu siswa membuat berbagai jawaban yang berbeda dan benar. Berikut Gambar 2. Struktur model Proses Kreativitas Siswa dalam Menyelesaikan Masalah Ill Structured Mathematical Problem pada Komponen Fluency, Flexibility, dan Novelty. 


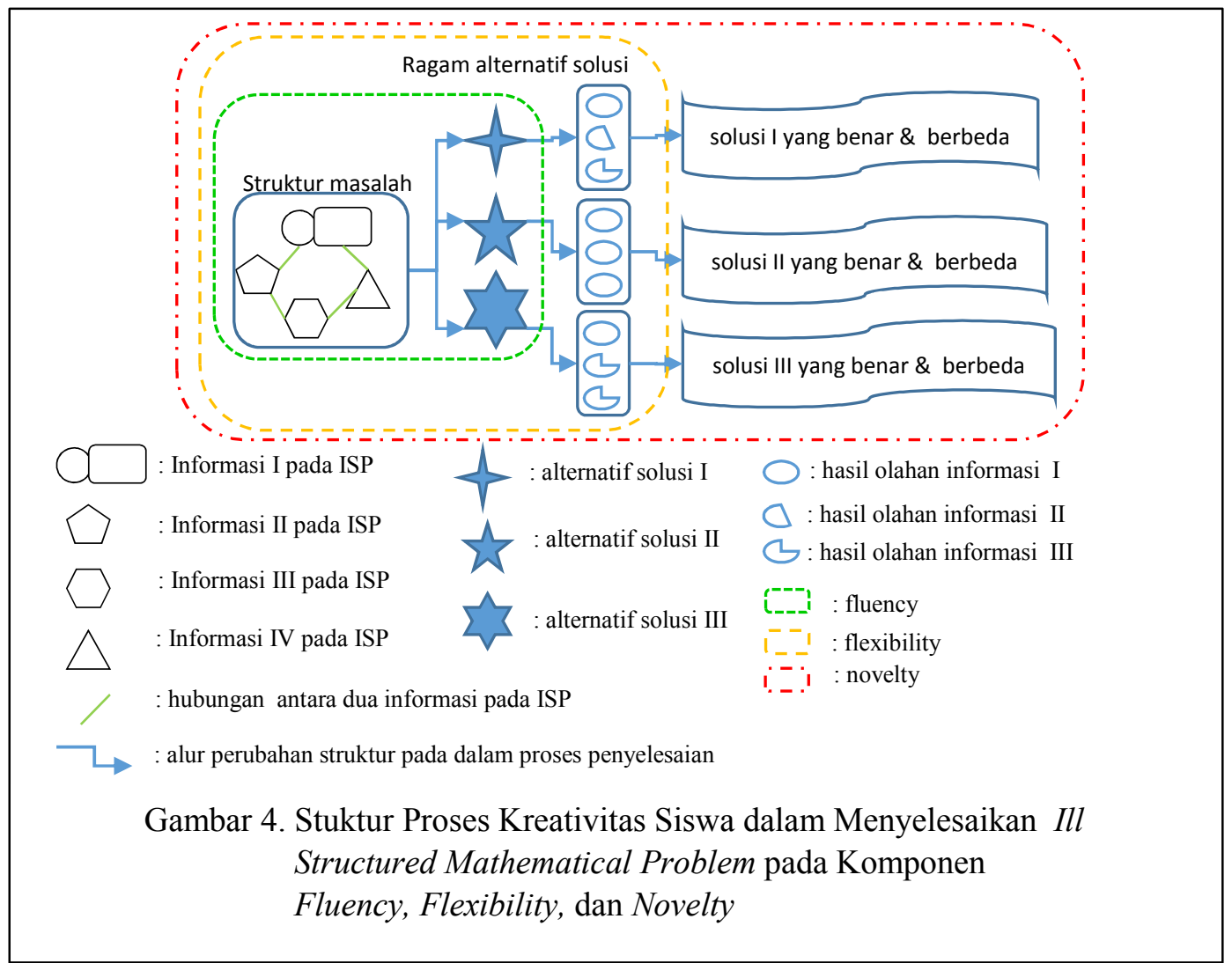

\section{KESIMPULAN}

Munculnya kreativitas siswa terjadi melalui proses 1) membuat jawaban yang beragam dan benar dalam memecahkan masalah (fluency), karena ISMP memiliki beberapa jalur solusi; kemudian 2) memecahkan masalah dengan berbagai cara yang berbeda (flexibility), karena ISMP memiliki konteks yang spesifik dan situasi yang kompleks; dan 3) membuat berbagai jawaban yang berbeda dan benar dalam memecahkan masalah (novelty) karena ISMP sesuai dengan kehidupan sehari-hari sehingga siswa merasa mengalami masalah tersebut.

\section{DAFTAR RUJUKAN}

Abdillah, Nusantara, T., Subanji, Susanto, H., \& Abadyo. (2016). The Students Decision Making in Solving Discount Problem. International Education Studies, 9(7), 57-63.

Abdillah, Nusantara, T., Subanji, Susanto, H. (2017). Proses Berpikir Siswa dalam Menyelesaikan Ill Structured Problems Matematika. Prosiding Seminar Nasional Pendidikan Matematika, Program Studi Pendidikan Matematika Pascasarjana Universitas Negeri Malang. 1(1), 517-527. 
Ayllón, M., Gómez, I., \& Ballesta-Claver, J. (2016). Mathematical thinking and creativity through mathematical problem posing and solving. Propósitos $y$ Representaciones, 4(1), 169-218.

Chi, M. T. H. \& Glaser, R. (1985). Problem solving ability. In R. J. Sternberg (Ed.), Human abilities: An information-processing approach (pp. 227-250). New York: W.H. Freeman \& Co.

Creswell, J. W. (2012). Research Design: Qualitative, Quantitative, and Mixed Methods Approaches. 3rd Edition. Los Angeles: Sage Publications, Inc.

Depdiknas. (2003). Peraturan Menteri Pendidikan Nasional Republik Indonesia Nomor 20, Tahun 2003, tentang Standar Proses dalam Pendidikan Matematika.

Jonassen, D. H. (1997). Instructional design models for well-structured \& ill-structured problem-solving learning outcomes. Educational Technology Research \& Development, 45(1): 65-94.

Karwowski, M., Jankowska, D.M., and Szwajkowski, W. (2017). Creativity, Imagination, and Early Mathematics Education. Springer International Publishing Switzerland 20177 R. Leikin, B. Sriraman (eds.), Creativity and Giftedness, Advances in Mathematics Education.

Kim, M. K., Lee, J., Hong, J. Y., \& Kim, E. K. (2011). Study of 'Ill-Structured' status from mathematics problems in elementary school textbooks. Journal of Learner-Centered Curriculum and Instruction, 11(2), 1-21.

Kitchener, K.S. (1983). Cognition, metacognition, \& epistemic cognition:A three-level model of cognitive processing. Human Development, 26(4): 222-232.

Miles, B. M. \& Huberman, M. (1992). Analisis Data Kualitatif Buku Sumber Tentang Metode-metode Baru. Jakarta: UIP.

National Council of Teacher of Mathematics (NCTM). (2000). Principles and standards for school mathematics. Reston, VA: The National Council of Teachers of Mathematics, Inc.

Palm, T. (2008). Impact of authenticity on sense making in word problem solving. Educational Studies in Mathematics, 67(1), 37-58.

Permendikbud No. 22 Tahun 2016 tentang Standar Proses https://drive.google.com/file/d/0BysfMxQdDzw2bHRYSmFRLVRBQUk/view

Sanders, S. (2016). Critical and Creative Thinkers in Mathematics Classrooms. Journal of Student Engagement: Education Maters, 6(1), 2016, 19-27 
Shin, N., Jonassen, H. D., \& McGee, S. (2003). Predictors of well-structured \& illstructured problem solving in an astronomy simulation. Journal of Research in Science Teaching, 40(1): 6-33.

Silver, E. A. (1997). Fostering creativity though instruction rich mathematical problemsolving and problemposing. International Reviews on Mathematical Education, 29(3): 75-80.

Voss, J. F., Wolfe, C. R., Lawrence, J. A., \& Engles, R. A. (1991). From representation to decision: an analysis of problem solving in international relations. In R. J. Sternberg (Ed.), Complex problem solving. Hillsdale, NJ: Lawrence Erlbaum Associates.

Wood, P.K. (1983). Inquiring systems \& problem structures: Implications for cognitive development. Human Development, 26(5): 249-265. 